\section{Comparison of Resistant Cultivars for Management of Bacterial Spot in Peppers}

\author{
Brent Rowell, ${ }^{1}$ \\ R. Terry Jones, ${ }^{2}$ \\ William Nesmith, ${ }^{3}$ and \\ John C. Snyder ${ }^{4}$
}

Additional index words. bell pepper, Capsicum annuum, bacterial leaf spot, Xanthomonas campestris pv. vesicatoria

Summary. Bacterial spot epidemics, caused by Xanthomonas campestris pv. vesicatoria (Doidge) Dye, continue to plague bell pepper (Capsicum annumm L.) growers in a number of southern and midwestern states. A 3-year study designed to compare cultivars and breeding lines under induced bacterial spot epidemic and bacterial spot-free conditions began soon after the first release of cultivars having the $B s 2$ gene for resistance to races 1 to 3 of the pathogen. Bacterial spot epidemics were created by transplanting 'Merlin' plants (inoculated with races 1 to 3 ) into plots of each test cultivar at an isolated location in eastern Kentucky. Plots of the same trial entries at a second location were kept free of

University of Kentucky Agricultural Experiment Station Publication no. 99-11-36. The authors gratefully acknowledge the hard work and technical assistance of Darrell Slone, Chris Lindon, Jack Downy, Janet Pfeiffer, and Dave Lowry together with financial support from participating seed companies. We would also like to thank Dr. David F. Ritchie and colleagues in the Plant Pathology Dept. at North Carolina State University for providing isolates and conducting race determination assays in support of this project. The cost of publishing this paper was defrayed in part by the payment of page charges. Under postal regulations, this paper therefore must be hereby marked advertisement solely to indicate this fact.

${ }^{1}$ Assistant professor and extension specialist, Department of Horticulture, N-318 Agr. Science North, University of Kentucky, Lexington, KY 40546-0091.

${ }^{2}$ Associate professor and extension specialist, Department of Horticulture, University of Kentucky, Lexington, KY 40546-0091.

${ }^{3}$ Professor and extension specialist, Department of Plant Pathology, University of Kentucky, Lexington, KY 40546-0091.

${ }^{4}$ Associate professor, Department of Horticulture, University of Kentucky, Lexington, KY 40546-0091. bacterial spot for 2 of the 3 years of trials; however, a moderate natural epidemic occurred at this location in 1996. Bacterial spot resistance had the greatest impact on yields and returns per acre in the inoculated trials. Cultivars with only $B s I$ or a combination of $B s I$ and $B s 3$ were highly susceptible in the inoculated trials. There were statistically significant and economically important differences in resistance among cultivars and breeding lines having the $B s 2$ gene; some were nearly as susceptible as susceptible checks. Although many $B s 2$-gene cultivars showed satisfactory levels of resistance, only a few were highly resistant, horticulturally acceptable, and comparable in yields to the best susceptible hybrids in a bacterial spot-free environment.

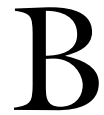
acterial spot has been a recurrent problem for fresh market, processing, and home garden pepper growers during Kentucky's hot, humid summers. Outof-state pepper processing companies used to supply growers with cheap bareroot transplants of open-pollinated cultivars that were sometimes infested with Xanthomonas campestris pv. vesicatoria $(X c v)$ causing bacterial leaf spot (BLS). Although carefully managed local transplant production has reduced the number of infested transplants brought into the state, BLS control has still not been very successful during wet growing seasons. Also, copper-tolerant strains of $X c \mathcal{v}$ are present in the state although the prevalence of these strains is not known. Severe epidemics occurred in Kentucky in 1973, 1985, 1991, and 1996, causing crop failures for some growers and substantial losses for many others. Only about 1500 acres (607 ha) of bell peppers are now grown in the state after a steady decline from 6000 acres ( 2428 ha) in 1973 . Other production regions share the BLS problem and most states bordering Kentucky report bacterial spot as their most serious infectious disease of pepper (W. Nesmith, unpublished).

\section{Resistance genes and Xcv races}

Any discussion of BLS resistance in peppers must begin with a description of the resistance genes employed and the multiple races of the pathogen. The gene symbols are confusing 
because they were named in the order of discovery and do not correspond to the $X c v$ races to which they confer resistance. It should also be understood that none of these genes confer immunity to disease but cause a rapid, limited necrosis of tissue (hypersensitive reaction, HR) resulting in lesions that are restricted in size with sharply defined margins (Cook and Stall, 1963). This resistant reaction limits further growth of the pathogen within the tissue and generally results in less damage to the plant relative to susceptible cultivars.

The three independent single dominant genes that plant breeders have employed in commercial cultivars are referred to as $B s I$ (HR to $X c v$ races 0,2 and 5 ), $B s 2$ (HR to races 0 , $1,2,3,7$ and 8 ), and $B s 3$ (HR to races $0,1,4,7$ and 9). Cultivars with $B s 2$ have been widely grown in recent years. Single gene resistance to some strains of race 6 and to races $0,1,3$, and 4 was recently identified in Capsicum pubescens R. \& P. (PI 235047) for which the Bs4 designation has been proposed (Sahin and Miller, 1998).

Although eleven $X c v$ races have been identified (Ritchie et al., 1998), only races $1,3,4$, and 6 are of economic importance in the United States at this time (D. F. Ritchie, personal communication). Races 4 and 6 are poised to cause the most immediate problems for growers using resistant cultivars having the $B s 2$ gene (Pernezny et al., 1998, Pernezny and Collins, 1999). Races 7 to 10 are presently of academic interest only.

Race 2 was predominant in Florida as far back as 1960 when race 1 was seldom detected; race 1 was routinely detected in surveys conducted in 1989 (Pohronezny et al., 1992). The frequency of race 3 detections rose among samples collected from the southeastern United States after 1992 (Romero et al., 1996) and became predominant in some areas (Sahin and Miller, 1996). Races 4, 5 , and 6 have been described since 1994 (Kousik and Ritchie, 1995; Pernezny and Collins, 1999; Sahin and Miller, 1995) and can overcome the $B s 2$ gene. Detections of races 4 and 6 have recently risen dramatically in southern Florida (Pernezny et al., 1998, Pernezny and Collins, 1999). First isolated from a 1993 sample in Ohio (Sahin and Miller, 1995), race 6 was also isolated from two samples from our 1995 inoculated trial in Ken- tucky and from two North Carolina samples in 1998 (D. F. Ritchie, unpublished). It has been hypothesized that this latest race shift may have occurred as a result of widespread use of resistant cultivars with the $B s 2$ gene (Pernezny and Collins, 1999).

Moderate to severe BLS epidemics occurred in plantings of resistant cultivars with $B s 2$ in southern Florida during the unusually wet 1997-98 winter growing season (Pernezny and Collins, 1999) and a milder epidemic occurred in the 1998-99 season; these have been associated with newly predominant race 6 in southeastern Florida and with race 4 in southwestern Florida (Pernezny et al., 1998, Pernezny and Collins, 1999). While epidemics have been severe in some fields and there are serious concerns over the potential damage from race 6 on $B s 2$ cultivars in southern Florida, there have as yet been no widespread and serious losses attributed to race 6 like those that were associated with race 3 a few years earlier (R. Hernendez and R. Subramanya, personal communication).

\section{Development of resistant cultivars}

Large-fruited, commercially acceptable bacterial spot resistant cultivars were unavailable until recently. The first cultivar having $B s 2$ with resistance to races 1 to 3 was released in 1983-84 but was never used commercially because of its small fruit size ( $R$. Stall, personal communication). The disease could be controlled at that time with copper sprays prior to the predominance of copper-tolerant $X \mathrm{CD}$ strains in Florida. The first large-fruited resistant cultivars with good horticultural characteristics were developed by Pepper Research Inc. (Belle Glade, Fla.) and Petoseed (Saticoy, Calif.) in 1989 and 1991, respectively. Race 2 resistance from $B s I$ in these cultivars was defeated by race 1 when this race became prevalent in Florida in 1990 91.

Pepper Research broke the small fruit size/late maturity linkages with the $B s 2$ gene and released the first successful commercial hybrid having this gene in 1994. Other companies soon followed with race 1,2,3-resistant $B s 2$ cultivars and with race 1,2resistant cultivars having both $B s I$ and $B s 3$. Hybrids with $B s 2$ have been widely grown during the past several years and have significantly reduced damage from bacterial spot epidemics in Florida and elsewhere. Although nearly all of the major seed companies promote one or more resistant cultivars with the Bs 2 gene, very few of these cultivars have been evaluated beyond the seedling stage under epidemic bacterial spot conditions in the field.

Some of the first resistant hybrids were planted in Kentucky farmers' fields for observation in 1994 and were the only plants with green foliage remaining at the end of the season. A major collaborative effort between the Department of Horticulture and the Department of Plant Pathology, University of Kentucky, began the following year to evaluate newly released BLSresistant pepper cultivars and advanced breeding lines. We tested entries under induced bacterial spot epidemic conditions and in a bacterial spot-free environment. The objectives of the study were to determine how resistant cultivars would perform under heavy disease pressure and to compare their yields and fruit quality characteristics with those of our best (but susceptible) hybrids under BLS-free conditions. Results from 3 years of trials at two locations are presented here.

\section{Materials and methods}

New cultivars, advanced breeding lines, and three of our recommended hybrids were tested for 3 years at two locations in Kentucky. Entries were evaluated each year for disease resistance, yield, and overall fruit appearance at an isolated location in eastern Kentucky at the Robinson Experiment Station in Quicksand (QSND) where plots were inoculated with four races of the pathogen in 1995 and three races in 1996 and 1997. The same field was used for all three years of the inoculated trials at QSND. The same entries were evaluated at the Horticultural Crops Research Station in Lexington (LEX) where preventive treatments were applied each year in an effort to keep the trials free of bacterial spot. Different fields were used for each of the 3 years of trials at LEX. Thirteen advanced breeding lines and newly released cultivars were tested in $1995 ; 17$ were evaluated in 1996 including 11 resistant entries from the 1995 trials. Thirteen resistant entries were tested in 1997 including eight from the 1996 trials. 'Merlin', 'North Star', and 'King Arthur' were included in each trial as susceptible checks. We 
considered 'King Arthur' a susceptible check even though it has race 2 resistance from Bsl. A total of eight cultivars were evaluated in all 3 years of trials at both locations including the three checks.

All entries were seeded in the greenhouse in LEX on 21 Mar. 1995 and 1996 and on 26 Mar. 1997. Seedlings were grown in 72-cell plastic trays and transplanted to the field 8 weeks after seeding. Plots consisted of 20 plants in double-rows on a raised bed (LEX) or two double-row beds of 20 plants each (QSND) with black plastic mulch and drip irrigation. Plants were spaced 12 (LEX) or 14 to 16 (QSND) inches ( $30 \mathrm{~cm}$ and 35 to 40 $\mathrm{cm})$ apart in double rows which were 15 inches $(38 \mathrm{~cm})$ apart. Beds were 6 $\mathrm{ft}(1.8 \mathrm{~m})$ apart from center to center. Plots were arranged in a randomized complete block design with four replications at each location. The total amount of preplant and fertigated $\mathrm{N}$ ranged from 54 to $100 \mathrm{lb} /$ acre (60 to $\left.112 \mathrm{~kg} \cdot \mathrm{ha}^{-1}\right)$ at QSND to 100 to 125 $\mathrm{lb} / \mathrm{acre}$ (112 to $140 \mathrm{~kg} \cdot \mathrm{ha}^{-1}$ ) at LEX; $\mathrm{P}$ and $\mathrm{K}$ were applied preplant according to soil test recommendations. Synthetic pyrethroid insecticides were applied as needed to control aphids and European corn borer. A tank mix of maneb [Maneb 80, a.i. at $1.2 \mathrm{lb} /$ acre $\left.\left(1.3 \mathrm{~kg} \cdot \mathrm{ha}^{-1}\right)\right]$ and fixed copper [Kocide, a.i. at $1 \mathrm{lb} /$ acre $\left(1.1 \mathrm{~kg} \cdot \mathrm{ha}^{-1}\right)$ ] was applied weekly as a foliar spray when possible at LEX; continuous rains occurring early in the season did not permit regular spray applications at LEX in 1996.

Mature green fruit were harvested four times at LEX in 1995-96 and three times in 1997; mature greens were harvested three times at QSND in 1995 and twice in 1996 and 1997. Marketable fruit were sorted by size, counted and weighed. Marketable size classes were extra large: $>3.5$ inches in diameter $(>8.9 \mathrm{~cm})$, large: $>3$ inches but $\leq 3.5$ inches in diameter $(>7.6 \mathrm{~cm}$, $\leq 8.9 \mathrm{~cm}$ ), and medium: $>2.5$ inches but $\leq 3$ inches in diameter $(>6.2 \mathrm{~cm}$, $\leq 7.6 \mathrm{~cm}$ ). Means of all variables were compared each year and at each location using Waller-Duncan's LSD ( $\mathrm{k}$ ratio $t$ tests, $P=0.05)$. An analysis of data combined over 3 years was used to compare the eight cultivars common to all trials at QSND; data were combined for 12 entries common to the last 2 years of trials at LEX.

Inoculation. Six- to seven-week- old transplants of the susceptible cultivar Merlin were inoculated in the greenhouse and used as BLS source plants in the field at QSND. Isolates of $X c v$ were obtained from D.F. Ritchie, Department of Plant Pathology, North Carolina State University; we used only races of the pathogen that had been previously detected in commercial samples from Kentucky. Inoculum was prepared by streaking each isolate onto five plates of yeast dextrose calcium carbonate medium. After the plates were incubated 2 to $4 \mathrm{~d}$, they were flooded with sterile tap water and a rubber policeman was used to scrape the colonies; these suspensions were diluted to $500 \mathrm{~mL}(16.9 \mathrm{fl} \mathrm{oz})$ in 1995 and 1996 or to $250 \mathrm{~mL}(8.4 \mathrm{fl} \mathrm{oz})$ in 1997. Every other plant in the flat was inoculated with each of races 1,2 , and 3 and a Kentucky tomato strain of $X c v$ (1995) or with races 1,2 , and 3 (1996 and 1997). A single leaf was used for each race and was inoculated twice (once on each side of the midrib). A needleless syringe was used to infiltrate approximately $2 \mathrm{~mL}$ of suspension ( $1 \mathrm{~mL}$ per inoculation site; 29.6 $\mathrm{mL}=1.0 \mathrm{fl} \mathrm{oz}$ ) through the underside of a single leaf to create water-soaked areas $\approx 0.2$ to 0.4 inches ( 5 to $10 \mathrm{~mm}$ ) in diameter. Plants were inoculated over a 4 to $5 \mathrm{~h}$ period and incubated on benches in the greenhouse for 24 to 36 $\mathrm{h}$ before taking them to the field. Inoculated plants were transplanted on the same day as the test entries.

Creating epidemics. Twenty plants of each test entry were transplanted to the inner two rows of the two beds in each plot at QSND. Twenty inoculated 'Merlin' plants were transplanted to the two outer rows of the same two beds for each entry. This planting arrangement resulted in uniform bacterial spot epidemics for three successive years without having to inoculate test entries directly and without using overhead irrigation.

Disease assessment. Disease reaction was measured by visual estimates of the percentage of leaves exhibiting lesions (\% BLS), and by rating the plants for the extent of leaf drop (1 to 5 scale, $1=$ no defoliation to $5=$ total defoliation). Plots were assessed three times during the growing season in 1995 and 1996 and four times in 1997. Percentage assessments (\% BLS) were used to calculate the area under the disease progress curve (AUDPC) for each entry. This variable, routinely used to describe or compare epidemics (Campbell and Madden, 1990), was considered together with \%BLS and defoliation ratings as overall indicators of resistance.

Race determinations. To determine which $X c v$ races were present in our trials at the end of the season, leaf samples were collected after the final harvest from the 1995, 1996, and 1997 inoculated trials in QSND and from the LEX trial in 1996. Pathogenic isolates from the 1995 and 1996 samples were sent to the plant disease diagnostic lab at North Carolina State University for race determinations where they were inoculated onto leaves of differential cultivars consisting of 'Early Calwonder' and three nearisogenic lines carrying $B s 1, B s 2$, or $B s 3$ (Hibberd et al., 1987).

Marketable yield vs. Returns. Average total marketable yields and yields of each size class were compared using Waller-Duncan's LSD ( $\mathrm{k}$ ratio $t$ tests, $\mathrm{P}=0.05)$. Results from individual trials have been published (Rowell et al. 1997a-c, 1998a-b). Although yields for each size class are important, we believe that the large tables of data usually reported are confusing and difficult for growers to interpret. Although reporting only total marketable yields simplifies matters, this variable is of limited practical use to commercial growers and can mask more important economic considerations. Yields of the largest size classes of peppers, for example, can make or break the season for a grower because of the higher prices received for these sizes. However, some cultivars with high total marketable yields might have been later in maturity with a large proportion of its marketable yield consisting of medium-sized peppers for which there is only a secondary market. Making planting decisions based on total marketable yield data alone could lead to disastrous results for a commercial grower.

Because the potential income or gross returns per acre may be a more useful way of evaluating yield data, we converted raw data by multiplying each size class yield by the appropriate price (wholesale price for that harvest date or average season price) for that class. The resulting single variable is a good indicator of a cultivar's overall performance, taking into account yields of the different size classes and their price differentials. 
Table 1. Yields, disease resistance, appearance, and gross returns for pepper cultivars exposed to induced bacterial spot epidemics at Quicksand, Ky., 1995-97. Data are means of four replications. Means of eight entries common to all 3 years of trials are shown in Table 3.

\begin{tabular}{|c|c|c|c|c|c|c|}
\hline \multirow[b]{2}{*}{ Entry } & \multirow[b]{2}{*}{$\begin{array}{l}\text { Known } \\
\text { resistance } \\
\text { gene }(s)^{z}\end{array}$} & \multicolumn{5}{|c|}{1995} \\
\hline & & $\begin{array}{c}\text { Tot. mkt. } \\
\text { yield }^{\mathrm{y}} \\
\text { (tons/acre) }\end{array}$ & $\begin{array}{r}\% \mathbf{L g} \\
+\mathbf{X} \mathbf{L}^{\mathbf{x}} \\
\end{array}$ & AUDPC $^{\mathbf{w}}$ & Appearance $^{\mathrm{v}}$ & $\begin{array}{l}\text { Income }^{u} \\
\text { (\$/acre) }\end{array}$ \\
\hline Boynton Bell & Bs1, Bs2 & 20.5 & 44 & 495 & 7.0 & 7945 \\
\hline X3R Lancelot & Bs2 & 19.7 & 50 & 460 & 4.0 & 7831 \\
\hline Summer Sweet 880 & Bs1, Bs2 & 17.9 & 32 & 748 & 7.0 & 6683 \\
\hline Summer Sweet 870 & Bs1, Bs2 & 17.4 & 35 & 454 & 7.0 & 6464 \\
\hline Commandant & Bs2 & 14.7 & 46 & 1185 & 7.5 & 5729 \\
\hline Enterprise & Bs2 & 14.6 & 44 & 1040 & 7.5 & 5654 \\
\hline PR 9300-8 & Bs1, Bs2 & 14.2 & 32 & 649 & 7.0 & 5277 \\
\hline PR 9300-5 & Bs1, Bs2 & 13.6 & 25 & 887 & 8.0 & 4940 \\
\hline Goldcoast & Bs2 & 11.7 & 46 & 759 & 7.0 & 4508 \\
\hline X3R Camelot & Bs2 & 10.5 & 48 & 1320 & 8.0 & 4147 \\
\hline X3R Wizard & Bs2 & 10.2 & 45 & 1761 & 7.0 & 3987 \\
\hline King Arthur & Bsl & 2.2 & 32 & 3268 & 4.0 & 802 \\
\hline Merlin & & 1.4 & 22 & 2901 & --- & 512 \\
\hline North Star & & 0.7 & 0 & 3082 & --- & 245 \\
\hline Guardian & Bs1, Bs3 & 1.1 & 34 & 3824 & --- & 409 \\
\hline Sentinel & Bs1, Bs3 & 0.3 & 0 & 3537 & --- & 112 \\
\hline X3R Aladdin & Bs2 & & & & & \\
\hline Combat & Bs2 & & & & & \\
\hline RPP 4136 & Bs2 & & & & & \\
\hline Sentry & Bs2 & & & & & \\
\hline Yorktown & Bs2 & & & & & \\
\hline Summer Sweet 830 & Bs1, Bs2 & & & & & \\
\hline ACX 204 & Bs1, Bs2 & & & & & \\
\hline E2312 & Bs2 & & & & & \\
\hline PR 9701R-5 & Bs1, Bs2 & & & & & \\
\hline Summer Sweet 890 & Bs1, Bs2 & & & & & \\
\hline Brigadier & Bs2 & & & & & \\
\hline PR 9701R-2 & Bs1, Bs2, Bs3 & & & & & \\
\hline Waller-Duncan LSD $(P<0.05)$ & & 3.2 & & 430 & & 1259 \\
\hline
\end{tabular}

'Presence of resistance genes for 'Boynton Bell', 'Summer Sweet 880', 'Summer Sweet 870', PR 9300-8, PR 9300-5, 'X3R Camelot', 'Guardian', 'Sentinel', PR 9701R-5, and PR 9701R-2 determined by Kousik and Ritchie (1998) or C. S. Kousik and R. Subramanya (unpublished). Seed company breeders report that 'X3R Lancelot', 'X3R Wizard', 'X3R Aladdin', 'Commandant', 'Enterprise', RPP 4136, 'Sentry', and 'Brigadier' have Bs2 only but that 'Summer Sweet 830', 'Summer Sweet 890', and ACX 204 carry Bs1 and Bs2. Other Bs2 cultivars listed are thought to have Bs2 only but may not have been tested for the presence of other resistance genes. yTotal marketable yield included yields ( 1 ton/acre $\left.=2.24 \mathrm{t} \cdot \mathrm{ha}^{-1}\right)$ of U.S. Fancy and No. 1 fruits of medium $(>2.5$ inches diameter, $>64$ mm $)$ size and larger

xPercentage of total yield, consisting of large ( $>3$ inches but $\leq 3.5$ inches diameter, $>76 \mathrm{~mm} \leq 89 \mathrm{~mm}$ ) and extra-large ( $>3.5$ inches diameter, $>89 \mathrm{~mm}$ ) fruits.

${ }^{\mathrm{w}} \mathrm{AUDPC}=$ area under the disease progress curve-used to compare epidemic development over time; higher values indicate less resistance.

Visual fruit appearance ratings where $\mathrm{l}$ = worst, 9 = best, taking into account overall attractiveness, shape, smoothness, degree of flattening, color, and uniformity of size/shape; ratings $\geq 6.0$ were considered to have the best potential for market acceptance.

"Income $=$ gross returns per acre $(\$ 1 /$ acre $=\$ 2.47 / \mathrm{ha})$; prices assigned for all years were $\$ 0.23 / \mathrm{lb}(\$ 0.5 \mathrm{l} / \mathrm{kg})$ for extra-large, $\$ 0.20 / \mathrm{lb}(\$ 0.44 / \mathrm{kg})$ for large, and $\$ 0.17 / \mathrm{lb}(\$ 0.37 / \mathrm{kg})$ for medium.

Fruit appearance ratings. All fruit of each cultivar from one replication at each location were graded and laid out on a table or in the field for careful examination and quality rating. The appearance ratings in Tables 1 and 2 took several things into account including, in order of importance: overall attractiveness, shape, smoothness, degree of "flattening", color, and uniformity of size/shape. We considered an average rating of 6 or above to have the greatest potential for market acceptance.

\section{Results}

1995 Trials. There were signifi- cant differences among cultivars and breeding lines for all variables tested in the inoculated trial at QSND in 1995 (Table 1). The degree of susceptibility to BLS had the greatest impact on yields (Fig. 1); there was a highly significant negative association between the percentage of leaves with symptoms (\% BLS) and total marketable yields $(r=-0.90, P<0.01)$. Average percentage of leaves with BLS symptoms ranged from 52 to 61 percent (data not shown) for the three susceptible checks. Resistance to bacterial spot was high (less than or equal to $25 \%$ BLS and AUDPC values less than 2000) for all entries tested with resis- tance to races 1,2 , and 3 (Bs2 gene) with the exception of 'X3R Wizard' which had $40 \%$ BLS (data not shown). There were also significant differences in yields and disease development among cultivars having the $B s 2$ gene with a surprising degree of apparent susceptibility in 'X3R Wizard'.

Marketable yields and income under severe disease pressure at QSND were highest for 'Boynton Bell', 'X3R Lancelot', 'Summer Sweet 870' and 'Summer Sweet 880'. Among these 'Boynton Bell' and 'Summer Sweet 870 ' had the most attractive fruit in 1995 (Table 1).

Cultivars and breeding lines from 


\begin{tabular}{|c|c|c|c|c|c|c|c|c|c|}
\hline \multicolumn{5}{|c|}{1996} & \multicolumn{5}{|c|}{1997} \\
\hline $\begin{array}{c}\text { Tot. mkt. } \\
\text { yield } \\
\text { (tons/acre) }\end{array}$ & $\begin{array}{l}\% \mathrm{Lg} \\
+\mathrm{XL} \\
\end{array}$ & AUDPC & Appearance & $\begin{array}{l}\text { Income } \\
\text { (\$/acre) }\end{array}$ & $\begin{array}{c}\text { Tot. mkt. } \\
\text { yield } \\
\text { (tons/acre) }\end{array}$ & $\begin{array}{l}\% \mathrm{Lg} \\
+\mathrm{XL} \\
\end{array}$ & AUDPC & Appearance & $\begin{array}{l}\text { Income } \\
\text { (\$/acre) }\end{array}$ \\
\hline 20.3 & 68 & 1605 & 7.0 & 8156 & 11.0 & 63 & 1079 & 6.0 & 4310 \\
\hline 20.4 & 67 & 1809 & 6.5 & 8330 & & & & & \\
\hline 23.0 & 55 & 1534 & 5.0 & 8956 & 15.6 & 58 & 774 & 4.0 & 6021 \\
\hline 19.2 & 69 & 2101 & 7.0 & 7841 & 13.2 & 66 & 1522 & 4.0 & 5239 \\
\hline 19.6 & 69 & 1532 & 6.0 & 7916 & 10.8 & 69 & 1324 & 5.0 & 4313 \\
\hline 18.6 & 70 & 1659 & 6.0 & 7549 & & & & & \\
\hline 18.7 & 53 & 1664 & 6.5 & 7124 & & & & & \\
\hline 15.3 & 68 & 2134 & 6.0 & 6192 & & & & & \\
\hline 9.8 & 76 & 2311 & 7.0 & 4102 & 6.1 & 68 & 1370 & 6.0 & 2438 \\
\hline 13.9 & 76 & 2161 & 7.0 & 5814 & & & & & \\
\hline 8.6 & 56 & 3415 & 5.0 & 3434 & 4.1 & 56 & 4031 & 4.0 & 1564 \\
\hline 8.6 & 47 & 3172 & 6.0 & 3294 & 1.8 & 43 & 4391 & - & 658 \\
\hline 10.4 & 44 & 2740 & 6.0 & 3935 & 1.1 & 23 & 4361 & - & 410 \\
\hline 19.1 & 71 & 1675 & 7.0 & 7872 & 10.2 & 71 & 1362 & 6.0 & 4155 \\
\hline 23.7 & 43 & 1394 & 6.0 & 8797 & & & & & \\
\hline 23.4 & 72 & 1292 & 5.0 & 9975 & & & & & \\
\hline 23.2 & 70 & 1545 & 5.0 & 9769 & & & & & \\
\hline 21.3 & 75 & 1696 & 7.0 & 8825 & 9.5 & 58 & 1405 & 6.0 & 3692 \\
\hline 18.0 & 50 & 1547 & 6.5 & 7017 & 9.9 & 64 & 1328 & 5.0 & 3904 \\
\hline \multirow[t]{6}{*}{17.8} & 54 & 1482 & 5.0 & 6853 & & & & & \\
\hline & & & & & 13.3 & 58 & 767 & 5.0 & 5135 \\
\hline & & & & & 12.9 & 71 & 727 & 6.0 & 5163 \\
\hline & & & & & 12.5 & 65 & 1035 & 6.0 & 4990 \\
\hline & & & & & 9.1 & 68 & 633 & 5.0 & 3624 \\
\hline & & & & & 8.6 & 67 & 1311 & 5.0 & 3355 \\
\hline 3.4 & & 305 & & 1366 & 3.1 & & 470 & & 1257 \\
\hline
\end{tabular}

this trial were grouped according to claimed race resistance and compared by single degree of freedom contrasts. Average total marketable yields were significantly higher and AUDPC values were significantly lower $(\mathrm{P}<0.05)$ for all cultivars with race 1 to 3 resistance $(B s 2)$ than for those with only race 1 and 2 resistance ('Guardian' and 'Sentinel', both with $B s I$ and $B s 3$ ). AUDPC values were significantly higher (more severe epidemics) for cultivars with only race 1 and 2 resistance than for two of the susceptible checks ('Merlin', 'North Star') with no claimed resistance. Cultivars with only race 1 and 2 resistance were

Fig. 1. Relationship between total marketable yields (1 ton/acre $=2.24$ t.ha-1) and bacterial spot symptoms on 16 bell pepper cultivars. Data plotted are means of four replications from the 1995 inoculated trial at Quicksand, Ky.

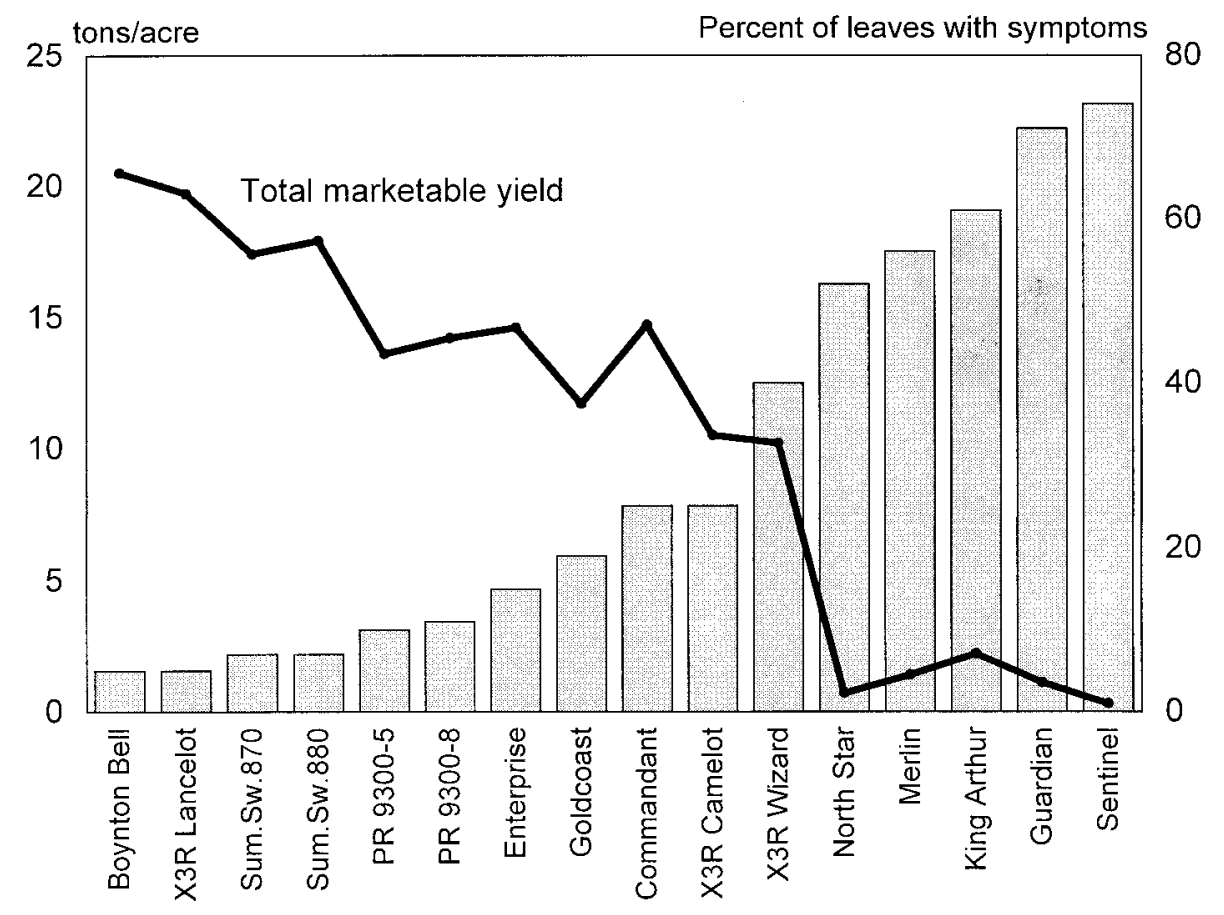


Table 2. Yields, disease resistance, appearance, and gross returns for pepper cultivars exposed to a moderate natural bacterial spot epidemic (1996) and under disease free conditions (1997) in Lexington, Ky. Data are means of four replications; the last three columns are from an analysis combining 1996 and 1997 data for 12 entries common to both years.

\begin{tabular}{|c|c|c|c|c|c|c|}
\hline \multirow[b]{2}{*}{ Entry } & \multicolumn{5}{|c|}{1996 Natural epidemic } & \multirow[b]{2}{*}{$\begin{array}{l}\text { Income }^{u} \\
\text { (\$/acre ) }\end{array}$} \\
\hline & $\begin{array}{c}\text { Tot. mkt. } \\
\text { yieldd } \\
\text { (tons/acre) } \\
\end{array}$ & $\begin{array}{r}\% \mathbf{L g} \\
+\mathbf{X L}^{\mathbf{y}} \\
\end{array}$ & \%BLS ${ }^{\mathbf{x}}$ & Defoliation $^{w}$ & Appearance ${ }^{\mathrm{v}}$ & \\
\hline Commandant & 21.7 & 65 & 0.0 & 1.0 & 6.0 & 8546 \\
\hline ACX 204 & 20.5 & 75 & 0.5 & 1.0 & 5.0 & 8044 \\
\hline RPP 4136 & 20.3 & 81 & 0.0 & 1.0 & 4.0 & 8715 \\
\hline Boynton Bell & 20.1 & 81 & 2.0 & 1.0 & 6.0 & 8314 \\
\hline Summer Sweet 870 & 20.1 & 64 & 0.5 & 1.0 & 6.0 & 7780 \\
\hline X3R Lancelot & 19.9 & 81 & 3.2 & 1.0 & 5.0 & 8429 \\
\hline Summer Sweet 830 & 19.9 & 69 & 2.7 & 1.0 & 5.0 & 7794 \\
\hline Sentry & 19.6 & 83 & 0.0 & 1.0 & 5.0 & 8364 \\
\hline Enterprise & 19.4 & 82 & 2.0 & 1.0 & 6.5 & 8096 \\
\hline Yorktown & 18.6 & 82 & 2.0 & 1.0 & 7.0 & 7594 \\
\hline PR 9300-8 & 18.1 & 63 & 1.5 & 1.0 & 7.0 & 7085 \\
\hline King Arthur & 18.0 & 82 & 50.0 & 2.5 & 6.0 & 7585 \\
\hline Goldcoast & 17.6 & 82 & 6.5 & 1.0 & 4.0 & 7286 \\
\hline X3R Aladdin & 17.5 & 68 & 0.5 & 1.0 & 7.0 & 6912 \\
\hline PR 9300-5 & 16.4 & 58 & 2.5 & 1.0 & 6.0 & 6292 \\
\hline X3R Wizard & 16.3 & 79 & 10.0 & 1.4 & 7.0 & 6778 \\
\hline Combat & 16.3 & 22 & 0.0 & 1.0 & 6.0 & 5832 \\
\hline North Star & 15.7 & 61 & 56.0 & 2.7 & 7.0 & 6079 \\
\hline Merlin & 15.5 & 71 & 52.0 & 3.0 & 7.0 & 6139 \\
\hline X3R Camelot & 13.1 & 73 & 39.0 & 2.0 & 7.0 & 5345 \\
\hline \multicolumn{7}{|l|}{ Paladin $(3135)^{t}$} \\
\hline \multicolumn{7}{|l|}{ PR 9701R-2 } \\
\hline \multicolumn{7}{|l|}{ Summer Sweet 890} \\
\hline \multicolumn{7}{|l|}{$3136^{\mathrm{t}}$} \\
\hline \multicolumn{7}{|l|}{ Brigadier } \\
\hline \multicolumn{7}{|l|}{$3505^{\mathrm{t}}$} \\
\hline \multicolumn{7}{|l|}{ PR 9701R-5 } \\
\hline \multicolumn{7}{|l|}{ E 2312} \\
\hline Waller-Duncan LSD $(\mathrm{P}<0.05)$ & 2.6 & & 5.5 & 0.25 & & 1147 \\
\hline
\end{tabular}

\footnotetext{
${ }^{2}$ Total marketable yield included yields ( 1 ton/acre $\left.=2.24 \mathrm{t} \cdot \mathrm{ha}^{-1}\right)$ of U.S. Fancy and No. I fruit of medium $(>2.5$ inches diameter, $>64 \mathrm{~mm})$ size and larger. yercentage of total vield consisting of large ( $>3$ inches but $\leq 3.5$ inches diameter, $>76 \mathrm{~mm} \leq 89 \mathrm{~mm}$ ) and extra-large $(>3.5$ inches diameter, $>89 \mathrm{~mm})$ fruit.

${ }^{\mathrm{B}} \mathrm{BS}$ = bacterial leafspot. Average percentage of leaves with bacterial spot symptoms; means of four replications from one assessment, 1996 only.

"Visual defoliation ratings where $\mathrm{l}=$ no defoliation, $5=$ completely defoliated; means of four replications from one assessment date, 1996 only.

"Visual fruit appearance ratings where $\mathrm{l}=$ worst, 9 = best, taking into account overall attractiveness, shape, smoothness, degree of flattening, color, and uniformity of size/shape; ratings $\geq 6.0$ were considered to have the best potential for market acceptance.

"Income $=$ gross returns per acre $(\$ 1 / \mathrm{acre}=\$ 2.47 / \mathrm{ha})$; prices assigned for all years were $\$ 0.23 / \mathrm{lb}(\$ 0.5 \mathrm{l} / \mathrm{kg})$ for extra-large, $\$ 0.20 / \mathrm{lb}(\$ 0.44 / \mathrm{kg})$ for large, and $\$ 0.17 / \mathrm{lb}(\$ 0.37 / \mathrm{kg})$ for mediums.

tPhytophtohora-tolerant (BLS susceptible) line.
}

dropped from further testing after this trial. Yields and AUDPC values for 'King Arthur' (considered a susceptible check but with race 2 resistance from $B s l$ ), were not significantly different from the other two susceptible checks nor from the cultivars with only race 1 and 2 resistance.

The uninoculated trial in Lexington was protected with weekly sprays of a copper+maneb tank mix and no BLS symptoms were observed on these plants during the entire season. There were significant differences among cultivars for marketable yields (data not shown). Our recommended BLSsusceptible cultivars 'Merlin' and 'North Star' performed well at LEX in the absence of bacterial spot. Entries that had high total marketable yields at both locations included 'Boynton Bell', 'Summer Sweet 880', and 'X3R Lancelot'. Entries with excellent resistance, acceptable marketable yields and good horticultural characteristics at both locations in 1995 were 'Boynton Bell', 'Summer Sweet 870', 'Enterprise', and 'PR 9300-5'. After seeing these results in the winter of 1995 , several Kentucky growers planted 'Boynton Bell' in 1996 and reported excellent yields in spite of epidemic leaf spot conditions resulting in losses of $50 \%$ and higher in fields of susceptible cultivars in the same areas.

1995 RAce composition. Race 3 of the pathogen was most often recovered ( $58 \%$ of 12 positive samples) from the end-of-season sampling from the QSND trial. Race 1 was detected in $25 \%$ of the samples. Race 6 , which was not artificially inoculated, was detected in two samples from this trial. This was the first time this race had been identified in a Kentucky sample. Race 3 appears to have caused the most damage in the inoculated trial as cultivars with only race 1 and 2 resistance were just as susceptible as checks having no claimed resistance.

1996 Trials. As in 1995, we intended to evaluate resistance under uniform epidemic conditions at QSND while keeping the LEX trial free of 


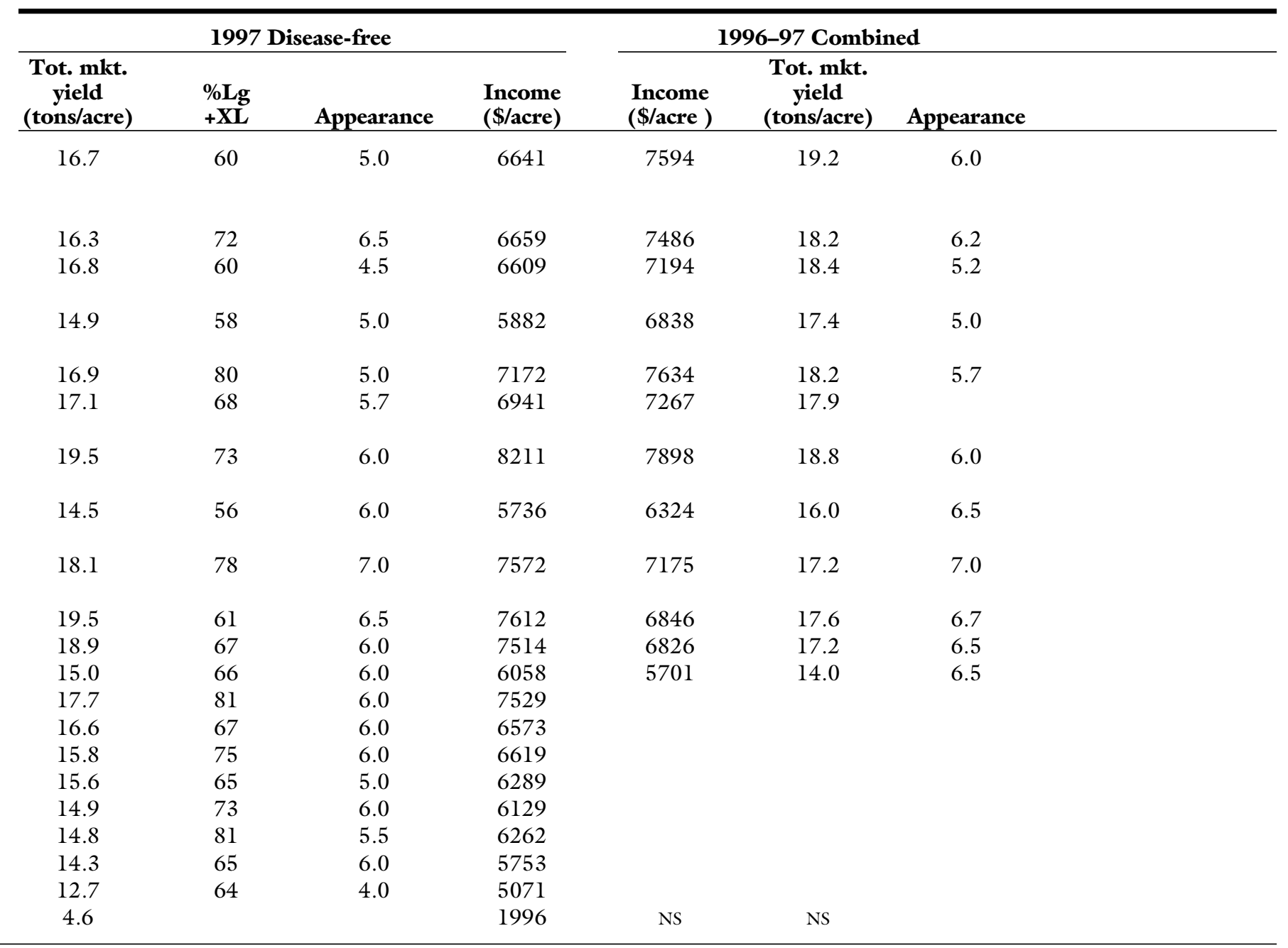

bacterial spot. However, heavy and continuous rains occurred soon after transplanting and BLS symptoms were soon observed among the susceptible checks in the LEX trial. Thus, a severe epidemic occurred in the inoculated trial at QSND and a natural, moderate epidemic occurred at LEX in the uninoculated trial. Total marketable yields at QSND were again closely associated with the degree of susceptibility to BLS. Marketable yields and $\%$ BLS $(r=-0.83, P<0.01)$ were negatively correlated as were marketable yields and the extent of leaf drop $(r=$ $-0.78, P<0.01)$.

In the inoculated trial, the average percentages of leaves with BLS symptoms were highest for the three susceptible checks and ranged from $47 \%$ to $58 \%$ (data not shown). Unexpectedly, four of the cultivars having the Bs2 gene ('X3R Camelot', 'X3R Wizard', 'Commandant', 'Goldcoast') from three different seed companies were somewhat susceptible to BLS under these conditions. This may be in part due to the occurrence of race 4 which, although not artificially inoculated, was detected in 11 samples from seven different cultivars in the trial. Average percentages of leaves with symptoms were higher than $30 \%$ for these four cultivars and were not significantly different from the average percentage of symptoms observed in susceptible 'North Star' (47\%). AUDPC values for all four of these cultivars were greater than 2000 but significantly lower than AUDPC values of susceptible cultivars 'Merlin', 'North Star', and 'King Arthur' (Table 1). The extent of leaf drop in 'X3R Wizard' and 'X3R Camelot' was also not significantly different from susceptible cultivars 'North Star' and 'Merlin' (data not shown).

Cultivars and breeding lines were assessed once for BLS symptoms in the LEX trial on 2 Aug., just prior to the third harvest. Negative correlations between marketable yield and \%BLS $(r$ $=-0.49, P<0.01)$ or marketable yield and the extent of defoliation $(r=-$ $0.51, P<0.01$ ) were highly significant but not as strong as in the more severe epidemic at QSND. The apparent susceptibility of some of the resistant cultivars was less evident in this more moderate (natural) epidemic than in the inoculated trial. However, plants of 'X3R Camelot' and 'X3R Wizard' had relatively high percentages of leaves with symptoms $(39 \%$ and $10 \%$ BLS, respectively), intermediate between other $B s 2$ entries and the susceptible checks (Table 2). No symptoms were observed on 'Commandant', RPP 4136, 'Sentry', or 'Combat' and most of the other resistant cultivars had less than 5 percent of leaves with symptoms (Table 2). 
Cultivars having the highest total marketable yields were not necessarily those with the highest income per acre in 1996 (Table 2). 'Combat' had the highest total marketable yield at QSND but ranked fifth in return per acre; this cultivar had the next to lowest return per acre in LEX (not significantly different from susceptible checks) because of its small fruit size. 'X3R Camelot' was also low yielding at both locations with the lowest gross return at LEX in spite of having the $B s 2$ gene.

Resistant entries we considered having the best overall yield and quality potential for our growing conditions in 1996 were 'Boynton Bell', 'Yorktown', and 'X3R Aladdin'. Other cultivars that were acceptable in terms of yields and fruit quality included PR 9300-8, 'Enterprise', and 'Commandant'. Some of the most resistant entries produced small fruit ('Combat') or the fruit had low appearance ratings at one or both locations (RPP 4136, 'Sentry', 'Summer Sweet 870').

1996 Race composition. Races 1 ( $53 \%$ of 36 positive samples), 4 (30\%), and $3(17 \%)$ were recovered from the inoculated trial at QSND. Leaf samples were also taken from two resistant cultivars exhibiting symptoms and from susceptible cultivars in the guard rows in the uninoculated LEX trial. Only race 1 was recovered from the LEX samples. Race 4 had not been previously reported in Kentucky.

1997 Trials. As in 1995 and 1996 , a uniform, severe epidemic developed rapidly after transplanting at QSND. In the inoculated trial at QSND, the average percentages ofleaves with BLS symptoms were highest for the three susceptible checks and ranged from $48 \%$ to $52 \%$ (data not shown). All resistant entries were significantly more resistant and higher yielding than the susceptible checks. Four entries (E2312, 'Summer Sweet 870', 'Brigadier' (PP 4153), and PR 9701R-5 had few symptoms and minimal leaf drop during the entire season; however, among these only PR 9701R-5 had high yields and appearance ratings $>\mathbf{5}$ in this trial (Table 1 ).

Under BLS-free conditions at LEX, susceptible cultivars 'King Arthur', 'North Star', and 'Merlin' were the highest yielding and had fruit appearance ratings of 6 or above (Table 2); however, some of the resistant hybrids performed nearly as well as the susceptible checks. Total marketable yields from 11 out of the 14 resistant entries in Table 2 were not significantly different from those for 'King Arthur' and 'North Star'. Incomes per acre for eight of the resistant entries were not significantly different 'King Arthur' which had the highest income (Table 2). Resistant cultivars tested under BLS-free conditions that had good overall yield and quality in 1997 were 'X3R Wizard', 'Boynton Bell', PR 9701R-2, 'Summer Sweet 890', and 'Yorktown'. 'Commandant', which looked promising in previous trials, had lower than expected appearance scores in 1997 and had more blossom end rot than other cultivars in the LEX trial. As in previous years, some highly resistant entries had low appear- ance ratings at one or both locations ('Summer Sweet 870', 'Summer Sweet 830', 'Commandant', 'Enterprise', E2312). 'X3R Wizard', which had not shown a high degree of resistance in past trials and was not tested in the inoculated trial, was very high yielding and had the highest appearance ratings in the BLS-free trial. This cultivar might be a good choice for locations where BLS is seldom a serious risk. Among three phytophthora (Phytophthora capsici Leonian) resistant (but BLS-susceptible) cultivars included in the BLS-free trial at LEX, 'Paladin' looked very good in terms of yields and quality under disease-free conditions (Table 2).

Combined analyses, 1995-97. The 1995, 1996, and 1997 inoculated trial data were combined for the eight entries common to all three trials and are summarized in Table 3. Among the five race 1 to 3 -resistant cultivars ( $B s 2)$ exposed to heavy disease pressure, 'Boynton Bell' (Bs $2+B s l)$ performed the best overall with the second highest income per acre and appearance ratings averaging higher than 6.5. 'Commandant' and 'Enterprise' also had income values not significantly less than that of 'Summer Sweet 870' which had the highest average income. Average appearance ratings for 'Summer Sweet 870' (5.3) and 'King Arthur' (4.3) were relatively low. There were insufficient numbers of fruit to evaluate appearance of susceptible cultivars 'Merlin' and 'North Star' in the inoculated trials. 'X3R Camelot' was significantly lower yielding with lower income per acre

Table 3. Means for eight cultivars common to 1995-97 Xantbomonas campestris pv. vesicatoria-inoculated trials at Quicksand, Ky. All data (except appearance ratings) are averages for 3 years with four replications per year.

\begin{tabular}{|c|c|c|c|c|c|c|c|}
\hline Boynton Bell & $B s 1, B s 2$ & 6804 & 17.3 & 6.7 & 14 & 1.5 & 1060 \\
\hline Commandant & $B s 2$ & 6270 & 15.7 & 6.2 & 23 & 2.1 & 1603 \\
\hline Enterprise & $B s 2$ & 5962 & 15.0 & 6.2 & 19 & 2.4 & 1299 \\
\hline King Arthur & $B s I$ & 1933 & 5.0 & 4.3 & 53 & 3.2 & 3571 \\
\hline North Star & --- & 1530 & 4.1 & --- & 50 & 3.3 & 3394 \\
\hline Merlin & --- & 1488 & 3.9 & --- & 52 & 3.1 & 3488 \\
\hline Waller-Duncan LSD & & 1362 & 3.7 & & 3.5 & 0.24 & 208 \\
\hline
\end{tabular}

${ }^{\mathrm{z}}$ Income $=$ gross returns per acre $(\$ \mathrm{l} / \mathrm{acre}=\$ 2.47 / \mathrm{ha}) ;$ prices assigned for all years were $\$ 0.23 / \mathrm{lb}(\$ 0.5 \mathrm{l} / \mathrm{kg})$ for extra-large, $\$ 0.20 / \mathrm{lb}(\$ 0.44 / \mathrm{kg})$ for large, and $\$ 0.17 / \mathrm{lb}$ $(\$ 0.37 / \mathrm{kg})$ for medium.

yTotal marketable yield ( 1 ton/acre $\left.=2.24 \mathrm{t} \cdot \mathrm{ha}^{-1}\right)$ included yields of U.S. Fancy and No. 1 fruit of medium $(>2.5$ inches diameter, $>64$ mm $)$ size and larger.

xVisual fruit appearance ratings where 1 = worst, 9 = best, taking into account overall attractiveness, shape, smoothness, degree of "flattening", color, and uniformity of size/ shape; ratings $\geq 6.0$ were considered to have the best potential for market acceptance.

${ }^{\text {wBLS }}$ = bacterial leafspot. Average percentage of leaves with bacterial spot symptoms; means of four replications from three (1995 and 1996) and four (1997) assessment dates.

visual defoliation ratings where 1 = no defoliation, 5 = completely defoliated; means of four replications from three (1995 and 1996$)$ and four (1997) assessments.

${ }^{\mathrm{u}} \mathrm{AUDPC}=$ area under the disease progress curve — used to compare epidemic development over time; higher values indicate less resistance. 
than the four other resistant cultivars but had less disease and was higher yielding than the susceptible checks. There were significant differences among resistant cultivars for the percentage of leaves with symptoms (\%BLS), extent of defoliation, and AUDPC values. 'Boynton Bell' and 'Summer Sweet 870' had fewer symptoms, less defoliation, and lower AUDPC values than the other cultivars tested (Table 3 ).

The 1996 and 1997 LEX trial data were also combined and analyzed for the 12 entries common to both years (last three columns in Table 2). These data represent average performance of cultivars under bacterial spot-free conditions in 1997 and under conditions of a moderate natural BLS epidemic in 1996. It was no surprise that the cultivar $\times$ year interactions were significant; susceptible cultivars were very high yielding in 1997 but much lower relative to resistant cultivars in 1996 due to the presence of bacterial spot in the 1996 trial. There were no statistically significant differences among these 12 cultivars for income or total marketable yields at this location when the cultivar $\times$ year interaction mean square was used as the error term in ANOVA. 'King Arthur' (considered susceptible, but with $B s I$ for race 2 resistance) had the highest average income over the two years in spite of considerable defoliation and a high percentage of leaves with symptoms in the 1996 trial. 'Enterprise' had the highest average income per acre among the four resistant cultivars although none of these differences among cultivars were statistically significant in the combined analysis. 'X3R Camelot' had the lowest marketable yield and income per acre among the 12 cultivars.

\section{Discussion}

Recently developed large-fruited bell pepper cultivars with single gene resistance to three races of $X c v$ have been quickly adopted by growers in states like Florida and Kentucky where moderate to severe epidemics regularly occur. A number of cultivars with the $B s 2$ gene are now on the market and many of these have provided good protection against races 1,2 , and 3 .

We successfully induced uniform bacterial spot epidemics in pepper cultivar trials at an isolated location for three years without having to inoculate test entries directly and without using overhead irrigation. Techniques employed appear to be reliable and repeatable and have generated results similar to growers' observations regarding some of the same cultivars in Kentucky as well as in Florida and New Jersey. In 1995, we determined that race 2 -resistant cultivars $(B s I)$ or cultivars with combined race 1 and 2 resistance $(B s I+B s 3)$ could not be recommended when race 3 was present. Most of the cultivars with $B s 2$ for resistance to races 1 to 3 showed satisfactory resistance under our field conditions. Only a few of these, however, also had yields and horticultural characteristics that were as good as the best susceptible cultivars under bacterial spot-free conditions.

We found economically important differences in degrees of resistance among resistant cultivars and breeding lines having the $B s 2$ gene. Surprisingly, some of the $B s 2$ cultivars appeared nearly as susceptible as susceptible checks in the 1995 and 1996 inoculated trials. Varying degrees of susceptibility among cultivars claiming resistance could be explained by any number of factors including differences in the number of single resistance genes, plant architecture, watersoaking ability of leaves, or varying degrees of severity of the hypersensitive response and associated leaf drop.

Kousik and Richie (1996, 1998) attributed better resistance in some cultivars to possible additive gene effects when $B s 2$ was combined with $B s I$ and/or Bs3. 'Boynton Bell', 'Summer Sweet 870', PR 9300-5, and PR 93008 , consistently among the more resistant entries in our trials, all have $B s I$ (resistance to races 2 and 5 ) in addition to $B s 2$ (races 1 to 3 ). However, all four of these entries came out of the same breeding program and have similar backgrounds apart from single resistance genes. Additive effects from combining single genes may not explain the differences we observed among cultivars: there were many examples of entries known to have only Bs 2 that appeared to be just as resistant as those possessing $B s I$ and $B s 2$. Six of the 12 Bs2-only entries were as resistant (AUDPC values not significantly different) as the most resistant entry among the six $B s 2+B s l$ entries tested in 1996 (Table 1). The same was true for two out of six Bs2-only entries in 1995 and for three out of seven Bs2-only entries in 1997. Additionally, in 1997, all seven $B s 2$-only entries were as resistant as the only entry known to have three resistance genes (PR 9701R-2: $B s 1, B s 2, B s 3)$.

It is likely that differing degrees of quantitative resistance in one or both parent lines used to make the $B s 2$ hybrids have as great or greater impact on disease development than combining $B s 2$ with other single genes. It is known, for example, that an 'Early Calwonder' background contributes more towards partial resistance in hybrids than does a 'Yolo' background. Breeders and researchers have long observed differences in partial resistance to bacterial spot among commercial cultivars and breeding lines without any of the single dominant resistance genes (Hibberd, 1989).

Improvements in screening techniques over the past 15 years have led to the development of some promising new breeding materials with quantitative resistance to bacterial spot ( $\mathrm{R}$. Stall, personal communication). It should be possible to develop horticulturally superior cultivars combining one or more single resistance genes with effective quantitative resistance. It might even be possible to choose single gene resistance in such cultivars that would provide selection pressure favoring less aggressive races of the pathogen.

Pohronezny et al. (1992) stated that the previous shift in the predominance of race 2 to race 1 in Florida did not appear to be caused by host selection (i.e., the planting of race 2 -resistant cultivars) and hypothesized that this shift could have occurred as a result of new pathotypes coming in at very low frequencies on hybrid seed produced elsewhere. This appears to have been the case for a new race of $X c v$ on tomato that occurred in Florida and which was also isolated from seed produced in Thailand (Jones et al., $1995)$. Research efforts need to continue to look for more sensitive seed testing techniques and better seed treatments to prevent possible movement of new races of the pathogen to and from seed production regions.

Leaf spot bacteria can grow and proliferate epiphytically on leaf surfaces prior to invading the host. Any cultural practice affecting these epiphytic populations could potentially affect leaf spot epidemics. There are good indications that we may be underestimating the impacts of cultural practices on the outbreak and severity of bacterial spot epidemics. Simons et 
al. (1994), having observed BLS epidemics in southern Florida over a 15 year period, reported that farms practicing good water management consistently had much less BLS. In addition, many BLS outbreaks were associated with stress-inducing cultural practices such as excess $\mathrm{N}$ fertilization or poorly drained fields subject to flooding and subsequent salt damage. In Kentucky, we have observed more severe epidemics associated with excess $\mathrm{N}$ and low K fertilization. Such observations call for further research to better establish these relationships and to identify those cultural practices most effective in reducing the risk from bacterial spot epidemics.

We will continue to recommend that pepper growers choose horticulturally acceptable resistant cultivars, grow their own transplants using sodium or calcium hypochlorite-treated seed, practice strict greenhouse and field sanitation, maintain copper + maneb spray routines, and maintain a uniform moisture supply to plants with the appropriate use of raised beds, plastic mulch and drip irrigation.

\section{Literature cited}

Campbell, C.L. and L.V. Madden. 1990. Introduction to plant disease epidemiology. Wiley, New York.

Cook, A.A. and R.E. Stall. 1963. Inheritance of resistance in pepper to bacterial spot. Phytopathology 53:1060-1062.

Hibberd, A.M., M.J. Bassett, and R. Stall. 1987. Allelism tests of three dominant genes for hypersensitive resistance to bacterial spot of pepper. Phytopathology 77:1304-1307.

Hibberd, A.M. 1989. Quantitative resistance to bacterial leafspot of pepper compared in mono and polycyclic disease progress tests, p. 213-219. In: S. K. Green (ed.). Tomato and pepper production in the tropics. Proc. Intl. Symp. Integrated Mgt. Practices, Asian Veg. Res. and Dev. Ctr., Tainan, Taiwan, 21-26 Mar. 1988.

Jones, J.B., R.E. Stall, J.W. Scott, G.C. Somodi, H. Bouzar, and N.C. Hodge. 1995. A third tomato race of Xanthomonas campestris pv. vesicatoria. Plant Dis. 79:395-398.

Kousik, C.S. and D.F. Ritchie. 1995. Isolation of pepper races 4 and 5 of Xanthomonas campestris pv. vesicatoria from diseased peppers in southeastern U.S. fields. Plant Dis. 79:540.

Kousik, C.S. and D.F. Ritchie. 1996. Disease potential of pepper bacterial spot pathogen races that overcome the $B s 2$ gene for resistance. Phytopathology 86:13361343.

Kousik, C.S. and D.F. Ritchie. 1998. Response of bell pepper cultivars to bacterial spot pathogen races that individually overcome major resistance genes. Plant Dis. 82:181-186.

Pernezny, K., R. Stall, K. Shuler, J. Collins, and M. Hewitt. 1998. Results of a survey of bacterial spot races (Xanthomonas campestris pv. vesicatoria) in south Florida, Spring 1998. Palm Beach County Ext. Rpt. 1998-99, August 1998.

Pernezny, K. and J. Collins. 1999. A serious outbreak of race 6 of Xanthomonas campestris pv. vesicatoria on pepper in southern Florida. Plant Dis. 83:79.

Pohronezny, K., R.E. Stall, B.I. Canteros, M. Kegley, L.E. Datnoff, and R. Subramanya. 1992. Sudden shift in the prevalent race of Xanthomonas campestris pv. vesicatoria in pepper fields in southern Florida. Plant Dis. 76:118-120.

Ritchie, D.F., C.S. Kousik, and T.C. Paxton. 1998. Response of bacterial spot pathogen strains to four major resistance genes in pepper, p. 14. In: Proc. Natl. Pepper Conf., San Antonio, 13-15 Oct. 1998.

Romero, A.M., C.S. Kousik, and D.F. Ritchie. 1996. Characteristics of Xanthomonascampestrispv. vesicatoria race
3 strains isolated from pepper. Phytopathology 86(Suppl.):S78 (abstr.).

Rowell, B., R.T. Jones, W. Nesmith, J. Doney, and J. Snyder. 1997a. Bell pepper cultivar evaluations for bacterial spot resistance, yields, and horticultural characteristics, 1995. Biol. Cult. Tests Control Plant Dis. 12:154.

Rowell, B., R.T. Jones, W. Nesmith, J. Doney, and J. Snyder. 1997b. Bell pepper cultivar evaluations for bacterial spot resistance, yields, and horticultural characteristics, 1996. Biol. Cult. Tests Control Plant Dis. 12:155.

Rowell, B., R.T. Jones, W. Nesmith, J. Doney, and J. Snyder. 1997c. Reactions of bell pepper cultivars to a natural bacterial spot epidemic, 1996. Biol. Cult. Tests Control Plant Dis. 12:156.

Rowell, B., R.T. Jones, W. Nesmith, J. Doney, and J. Snyder. 1998a. Bell pepper cultivar evaluations for bacterial spot resistance, 1997. Biol. Cult. Tests Control Plant Dis. 13:167.

Rowell, B., R.T. Jones, W. Nesmith, and J. C. Snyder. 1998b. Bacterial spot resistance, yield, and quality of bell pepper cultivars in epidemic and disease-free environments, p. 39-40. In: Proc. Natl. Pepper Conf., San Antonio, 13-15 Oct. 1998.

Sahin, F. and S.A. Miller. 1995. First report of pepper race 6 of Xanthomonas campestris pv. vesicatoria, causal agent of bacterial spot of pepper. Plant Dis. 79:118.

Sahin, F. and S.A. Miller. 1996. Characterization of Ohio strains of Xanthomonas campestris pv. vesicatoria, causal agent of bacterial spot of pepper. Plant Dis. 80:773778.

Sahin, F. and S.A. Miller. 1998. Resistance in Capsicum pubescens to Xanthomonas campestris pv. vesicatoria pepper race 6 . Plant Dis. 82:794-799.

Simons, J.N., J.E. Simons, and J.L. Simons. 1994. Plant stress as a predisposing factor in outbreaks of bacterial leafspot. Proc. Fla. State Hort. Soc. 107:387-397. 